\begin{tabular}{|c|c|c|c|}
\hline $\begin{array}{l}\text { KULTURA } \\
\text { i } \\
\text { SPOHFCTF木'TTWO }\end{array}$ & $\begin{array}{l}\text { POLSKA } \\
\text { KOMITET } \\
\text { INSTYTUT }\end{array}$ & $\begin{array}{l}\text { AKADEMIA NAUK } \\
\text { SOCJOLOGII } \\
\text { T STUDIÓW POLITYCZNYCH }\end{array}$ & ISSN 0023-5172 \\
\hline SPULCLLNSIMU & 2015, nr 1 & CZYTAJĄC ELIASA & \\
\hline
\end{tabular}

ŁUKASZ M. DOMINIAK

Uniwersytet Mikotaja Kopernika $w$ Toruniu

\title{
O SOCJOLOGII TWÓRCZOŚCI NAUKOWEJ NA MARGINESIE BIOGRAFII NORBERTA ELIASA
}

Każda historia domaga się bohaterów. Nie inaczej jest w przypadku historii nauk społecznych, której uczestnicy ponadto - i w przeciwieństwie do przedstawicieli innych nauk - sami tworzą narracje mające na celu przede wszystkim uzgodnić rangę własnych dokonań z osiągnięciami poprzedników, łącząc różnorodne praktyki naukowe w międzypokoleniową tradycję uprawiania zawodu. Powstający w ten sposób jednorodny obraz ewoluujących szkół myśli spełnia ważną funkcję więziotwórczą, nie pozostawiając jednak miejsca na dociekania historiograficzne i teoretyczne. W związku z tym rzadko zdarza się, aby historia nauk społecznych, w tym socjologii, miała na celu coś więcej niż upamiętnianie, co z kolei odbija się negatywnie na stanie jej teorii.

Powyższe przypuszczenie na temat roli historii socjologii i postrzegania jej przez samych socjologów chciałbym uwiarygodnić przykładem Norberta Eliasa. Socjolog ten, urodzony w 1897 roku we Wrocławiu, od kilku dziesięcioleci znajduje się w centrum zainteresowań coraz szerszego kręgu badaczy, nie tylko historyków i teoretyków socjologii. Elias jest jednym z najczęściej cytowanych socjologów XXI wieku ${ }^{1}$, a literatura egzegetyczna dotycząca jego dzieła oraz inspirowana jego badaniami wielokrotnie zrekompensowała pierwotny stan zapomnienia autora $O$ procesie cywilizacji.

\section{Adres do korespondencji: lukasz@umk.pl}

${ }^{1} \mathrm{~W}$ zestawieniu przygotowanym na stronie International Sociological Association The Civilizing Process Eliasa znajduje się na siódmym miejscu wśród stu książek socjologicznych uznanych przez członków ISA za najważniejsze (http://www.isa-sociology.org/books/vt/bkv_000.htm). 
Zamierzam przyjrzeć się powrotowi Eliasa do centrum socjologicznych zainteresowań. Uwagę zwraca przede wszystkim status socjologa "ponownie odkrytego” czy „Wcześniej zapomnianego”, uzasadniany przez dość pośpieszne przywoływanie wielu niemal fatalistycznych argumentów dotyczących splątania losów Eliasa ze zdarzeniami XX wieku, których był uczestnikiem w ciągu swojego długiego życia. Nie ma potrzeby dyskutować z faktami, że Elias bezpośrednio doświadczył obu wojen światowych, kryzysu ekonomicznego, antysemityzmu, emigracji, dekolonizacji, zimnej wojny. Jednak porównanie biografii indywidualnej odzwierciedlającej w skali mikro wymienione problemy z powszechnie znanymi chronologiami nie wyjaśnia fenomenu „Eliasa jako geniusza", ponieważ nie wszystkie jednostki, ani z pewnością nie wszyscy socjologowie lub uczeni wrzuceni w dwudziestowieczny tygiel dziejowy, nawet obdarowani długowiecznością, mogą poszczycić się takimi dokonaniami naukowymi jak Elias.

Marta Bucholc (2013, s. 256-259) słusznie zwraca uwagę, że wokół autora $O$ procesie cywilizacji wytworzyła się, oparta na Norbert Elias Foundation, grupa zarządzająca jego spuścizną i wizerunkiem, odpowiedzialna także za jego odkrywanie i uporządkowanie jego biografii.

Jeśli więc wyjątkowość Eliasa od kilku dekad jest przedmiotem instytucjonalnej pracy, w pewnej mierze oderwanej od jej wartości pierwotnej, to co właściwie stanowi ową wyjątkowość, poza estetycznymi lub quasi-mitologicznymi, etykietkami, takimi jak „status emigranta”, „długowieczność”, „interdyscyplinarność”? Postaram się odpowiedzieć na to pytanie, wyjaśniając jednocześnie samą kategorię wyjątkowości w twórczości naukowej z pomocą teorii rytuałów interakcyjnych (zob. Collins 1998, s. 19-63; 2011, rozdz. 5).

Powołując się na dość dowolnie dobierane biograficzne szczegóły, wyjątkowość Eliasa często uznaje się za pochodną jego samotności, specyficznego trybu życia zawodowego i osobistego, naznaczonego rozstaniami i gwałtownym zrywaniem więzi społecznych. Rzeczywiście autor $O$ procesie cywilizacji nie założył rodziny, a część jego krewnych, w tym matka, zginęła podczas drugiej wojny światowej.

Przywołując te zdarzenia jako formujące tożsamość autora pomija się jednak znaczenie jego powiązań $z$ grupami rówieśniczymi na różnych etapach życia. Okres dzieciństwa i młodości przed pierwszą wojną światową, zgodnie ze świadectwami autobiograficznymi, przebiegał w atmosferze odpowiedniej dla stylu niemieckiej klasy średniej i spokojnego, choć podporządkowanego interesom ekonomicznym, życia rodzinnego rozłożonego między Wrocławiem a Berlinem. Warto wspomnieć okres edukacji w Johannesgymnasium we Wrocławiu. Nastoletni Norbert Elias socjalizował się tam według norm klasycznego niemieckiego wykształcenia, z klasycznymi lekturami Goethego i Schillera. Kadra szkoły średniej wywierała pozytywny, humanistyczny wpływ na swoich wychowanków, co w opinii Eliasa było sprzyjającą okolicznością (Elias 2013a, s. 6-7; 2013b, s. 291). Nie ma powodów, aby sądzić, że do osiągnięcia 
dojrzałości Elias doświadczył jakichś form anomicznej samotności czy wykluczenia.

Okres służby wojskowej (1915-1917) z braku wiarygodnych źródeł trudno jest ocenić w proponowanej perspektywie.

Po demobilizacji i rozpoczęciu studiów należy odnotować aktywność Eliasa jako jednego $z$ liderów grupy Blau-Weiss w latach 1919-1923 na śląskim uniwersytecie Fryderyka Wilhelma we Wrocławiu. Organizacja ta zrzeszała młodych żydowskich intelektualistów o różnych poglądach syjonistycznych. Elias odgrywał wśród nich (byli to między innymi Erich Fromm, Gershom Sholem, Martin Buber, Leo Löwenthal, Martin Bandmann) niepoślednią rolę jako jeden $z$ tworzących program działalności grupy (Hackeschmidt 1997).

Studia Elias kontynuował z zamiarem napisania doktoratu i poświęcenia się nauce. Najpierw studiował medycynę i filozofię we Wrocławiu, następnie uczestniczył w spotkaniach salonu Marianny i Alfreda Weberów w Heidelbergu, później asystował Karlowi Mannheimowi we Frankfurcie nad Menem.

Wbrew obrazowej legendzie - Elias opuszczający biuro we Frankfurcie z maszyną do pisania pod pachą i jedną walizką — okresu emigracji również nie można zaliczyć na poczet doświadczeń samotności czy wygnania. Zarówno w Paryżu, jak i w Londynie oraz Leicester w latach trzydziestych, czterdziestych i pięćdziesiątych XX wieku znajdujemy Eliasa wśród podobnych jemu emigrantów i intelektualistów pochodzenia żydowskiego, pod skromną, ale stałą opieką organizacji świadczących pomoc wychodźcom. Nawet w czasie niemal rocznego internowania jako enemy alien w obozie na wyspie Man Elias odnalazł się wśród współtowarzyszy niedoli i zaangażował ich w działalność literacko-teatralną.

Po drugiej wojnie światowej uczestniczył jako uczony i dydaktyk w pracach peryferyjnych, ale prężnie działających instytucji naukowych, jak Group Analytic Society (1941-1954) oraz Instytut Socjologii na Uniwersytecie w Leicester (1954-1975) (Rojek 2004). Domniemanej samotności można doszukiwać się, moim zdaniem, jedynie w ostatnich piętnastu latach życia, które Elias spędził między Bielefeld a Amsterdamem otoczony współpracownikami młodszymi od siebie przynajmniej o jedno lub nawet dwa pokolenia. Byli to między innymi Johan Goudsblom, Hermann Korte, Stephen Mennell. Paradoksalnie, dopiero po założeniu przez nich w 1983 roku Norbert Elias Foundation Elias mógł najdobitniej odczuć samotność swojego życia. Znaczna część jego najbliższych przyjaciół wtedy już nie żyła (Karl Mannheim, Siegfried Heinrich Fuchs) lub byli oni nieaktywni ze względów zdrowotnych (Ilya Neustadt), a wszystkie jego najważniejsze prace w połowie lat osiemdziesiątych zostały już przetłumaczone na dominujące języki, znane i doceniane. Refleksje dotyczące umierania i samotności, które znalazły wyraz w The Loneliness of Dying, były spowodowane nie tylko częstszymi pobytami Eliasa w szpitalu. Miały one związek przede wszystkim ze wzrostem samoświadomości własnego osamotnionego usytuowania społecznego. 
Dynamika powiązań rodzinnych Norberta Eliasa również przeczy tezie o jego wyjątkowej samotności. Jedyny syn Hermanna i Sophie Elias pozostawał w bliskich relacjach z dziećmi siostry swojego ojca. Poza utrzymywaniem korespondencji spotykał się z nimi od wczesnej młodości we Wrocławiu, poprzez pobyt w Anglii, aż po późne lata osiemdziesiąte w Tel Awiwie (Jitschin 2013).

Możemy również pośrednio wnioskować z kilku świadectw, że Elias dysponował znaczącym kapitałem społecznym $\mathrm{w}$ postaci szeroko rozumianej towarzyskości. Przez swoje otoczenie, złożone głównie z rodzin przyjaciół z fali emigracji po roku 1933, na długo przed okresem zawodowego uznania był postrzegany jako Das Mensch - człowiek oryginalny, niełatwy w nawiązywaniu i utrzymywaniu relacji, jednak zdolny kumulować i przekazywać energię emocjonalną poprzez ekspresywny styl pisarski oraz odpowiedni dla uczonego sposób konwersacji (Seglow 2013).

Zatrzymam się w tym miejscu na chwilę przy kategorii energii emocjonalnej (dalej EE), którą za Randallem Collinsem uznaję za podstawową dla opisu zdarzeń w toku historii grup uczonych. EE jest mierzalnym wskaźnikiem o określonym poziomie, czymś co konwencjonalnie określamy jako emocje, jednak różniącym się od nich długością trwania. Na przykład emocje, które doprowadziły do opowiedzenia, a następnie napisania Biesiady lub Upaniszad, powodują powstawanie podobnych odczuć u czytelników tych tekstów. EE w pewien potencjalny sposób jest więc zawarta w pozaorganicznych wehikułach, którymi w świecie uczonych są teksty, artykuły, wystąpienia itp. Przekaz EE odbywa się poprzez rytuały interakcyjne (RI) o różnym charakterze i stopniu intensywności, na przykład wykłady, seminaria, rozmowy, lektury itp. Dodatkowym wskaźnikiem, o jakim należy wspomnieć, jest kapitał kulturowy (KK), stopień w jakim dana jednostka (a konkretnie jej ciało, w tym zwłaszcza układ nerwowy) nabyła umiejętności odczytywania złożonych z symboli komunikatów. Wysoki kapitał kulturowy zapewnia szerszy dostęp do potencjalnych kanałów dystrybucji EE (Collins 1998, s. 28-30). W przypadku Norberta Eliasa mamy do czynienia ze średnio wysokim KK (bardzo dobre wykształcenie, ale typowe dla ówczesnej klasy średniej, znajomość kilku języków) i średnim endogennym potencjałem EE (względna introwersja, niechęć do pracy mało twórczej) przy bardzo dużej zdolności do akumulacji tego szczególnego zasobu dzięki długotrwałemu podłączaniu się do różnorodnych i płodnych strumieni EE znanych i dyskutowanych $\mathrm{w}$ pierwszej połowie XX wieku prądów intelektualnych, takich jak neokantyzm, psychoanaliza, marksizm.

Na podstawie powyższej argumentacji i przytoczonych opisów można wnioskować, że życie i dzieło Eliasa nie cechowało się niczym szczególnym. Jego sytuacja intelektualisty-emigranta była wręcz typowa dla wielu innych uczonych, zwłaszcza niemieckojęzycznych pochodzenia żydowskiego, którzy rozpoczynali działalność w czasach Republiki Weimarskiej (tj. Walter Benjamin, Eric Voegelin, Leo Strauss, Hannah Arendt). Dorobek Eliasa jest wyjątkowo eklektyczny, niespójny i niełatwy do przyswojenia zarówno dla jego współczesnych, 
jak i obecnie. Powraca więc pytanie: co zatem stanowi o jego popularności? Przecież nie może być ona wytworem tylko i wyłącznie szkoły figuracyjnej, uczonych komentujących i reprodukujących w mniej lub bardziej twórczy sposób jego styl i zainteresowania.

Aby odpowiedzieć na to pytanie, należy na działalność Eliasa spojrzeć z innej perspektywy, w której oddzielone zostaną typowe zdarzenia biograficzne i bibliograficzne od realnych, historycznie zmiennych sieci powiązań między jednostkami obejmującymi jej otoczenie. W tym celu trzeba określić portret głównego bohatera tego tekstu zredukowany do stopnia intensywności uczestnictwa w poszczególnych grupach. Ma to posłużyć innemu spojrzeniu na marginalność Eliasa, która bynajmniej nie wynikała z przypadkowych kolei jego losu. W związku z tym nie ma również miejsca $\mathrm{w}$ tego rodzaju narracji na pośmiertne, niespodziewane odkrycie wcześniej nie znanego uczonego. Tego rodzaju przypadki mogą mieć miejsce tylko wtedy, gdy ktoś za życia zdoła wytworzyć odpowiednich rozmiarów sieci gwarantujące skuteczny przepływ idei rozumianych $\mathrm{w}$ tym przypadku jako ładunki energii emocjonalnej.

Prawdopodobieństwo zaistnienia warunków dla kreatywności intelektualnej jest mierzone głębokością, intensywnością i zasięgiem horyzontalnych oraz wertykalnych sieci łańcuchów rytuałów interakcyjnych, jakie dana jednostka jest w stanie wytworzyć, podtrzymać i do jakich jest w stanie podłączyć się w różnych okresach swojego życia. W przypadku Norberta Eliasa obie te zachodzące na siebie sieci, odzwierciedlające czasoprzestrzenną arenę jego intelektualnej pracy, są rzeczywiście imponujące i to one stanowią o jego wyjątkowości. Zacznę od umiejscowienia w niej dysertacji doktorskiej Eliasa.

Napisana pod kierunkiem neokantysty Richarda Hönigswalda praca pt. Idee und Individuum z jednej strony była kontynuacją podstawowych problemów zajmujących niemieckich filozofów przynajmniej od Immanuela Kanta, z drugiej zaś Elias już wtedy dystansował się od filozofii w ogóle i tradycji kantowskiej w szczególności. Dygresje dotyczące jego rozprawy doktorskiej nie są tutaj jednak istotne. Chodzi raczej o zwrócenie uwagi na fakt, że w latach dwudziestych $\mathrm{XX}$ wieku dynamika sieci powiązań, których efektem była również praca doktorska Eliasa, bardzo szybko słabła. Neokantyści byli już wtedy rozproszeni na trzy ośrodki; od 1910 roku to fenomenologia Husserla zdobywała coraz większe uznanie i w 1923 roku nic nie stało na przeszkodzie, aby uznać neokantyzm za ustępujący. Upadek tego nurtu wraz z powiązanym z nim pozytywizmem i psychologizmem tuż przed ukazaniem się Sein und Zeit wytworzył próżnię w postaci braku rozwiązań wobec odrodzenia metafizyki (Schnädelbach 1992, s. 296). Spory Eliasa o kilka stron jego umiarkowanie krytycznej dysertacji miały więc przesłanki na poziomie makro - przepływy energii emocjonalnej były wtedy tak słabe, że można było się im zarówno przeciwstawić, jak i zwrócić uwagę w innym kierunku. Była to sytuacja, która kilku innym absolwentom filozofii ułatwiła decyzję o zmianie zainteresowań - z metafizycznych w kierunku nauk społecznych (György Lukacs, Karl Mannheim, Theodor Adorno). 
W przypadku Eliasa była to sieć o znaczącym kapitale społecznym, jak wspomniany już salon intelektualny Marianny i Alfreda Weberów w Heidelbergu. Drobnomieszczańska i nieco dekadencka atmosfera czwartkowych seminariów również nie odpowiadała emocjonalnemu nastawieniu Eliasa, reprezentującego wtedy młode pokolenie niespełna trzydziestoletnich uczonych, wśród których był również jego przyszły teoretyczny rywal - Talcott Parsons.

Opuszczając kilka lat później Frankfurt nad Menem, Elias miał ze sobą ukończoną pracę habilitacyjną i raczej nie zakładał, że następne dwadzieścia lat zawodowo spędzi samotnie. Stan fizycznego oddzielenia nie jest jednak dla intelektualisty niczym wyjątkowym. Pracując samotnie w bibliotekach paryskich i w British Library, Elias w istocie pogłębiał sieci swoich powiązań interakcyjnych, tym razem w ich wymiarze czasowym, dochodząc do myślicieli Renesansu i najdawniejszych pokładów nowożytnej kultury europejskiej. Ukończywszy w ten sposób pracę nad rozszerzoną pracą habilitacyjną ( $O$ procesie cywilizacji) przeniósł się z Londynu do Leicester, gdzie wraz z Ilyą Neustadtem (1915-1993) zaangażował się (do roku 1975) w tworzenie peryferyjnego względem Oksfordu, Cambridge i London School of Economics ośrodka socjologicznego w ówczesnej Anglii. Pisał prace typowo socjologiczne między innymi o socjologii zawodów i socjologii urbanizacji i kontynuował z dużą intensywnością wymianę intelektualną (Goodwin, Hughes 2011). Dwie ostatnie dekady jego aktywności, poświęcone reedycjom, tłumaczeniom, pisaniu nowych wstępów, wpłynęły na znaczący wzrost zainteresowania jego dziełem, ale nie one zadecydowały, moim zdaniem, o jakościowej różnicy nadającej status klasyka, lecz wcześniejsze „podpięcie” Eliasowych analiz socjo-historycznych do rozległej sieci intelektualnej (po przetłumaczeniu jego prac na angielski pod koniec lat sześćdziesiątych) oraz jeszcze wcześniejsze bezpośrednie empiryczne umocowanie jego pisarstwa naukowego w historii kulturowej Europy i odniesienie do jej świadectw (Dominiak 2012).

W latach sześćdziesiątych XX wieku, kluczowych dla ukształtowania się merytorycznych podstaw legendy Norberta Eliasa, oprócz angielskiego tłumaczenia jego opus magnum powstaje wtedy mało znacząca na pierwszy rzut oka książka: The Established and the Outsiders: A Sociological Enquiry into Community Problems. Recenzje $z$ epoki nie pozostawiają złudzeń - jest to jedna $z$ wielu książek poświęconych popularnym ówcześnie w Wielkiej Brytanii urban studies, o pewnych zaletach teoretycznych i umiarkowanie odkrywczych wynikach, za to $z$ mankamentami metodologicznymi (Colfax 1966; Hoffsommer 1966). Ponieważ w socjologii polskiej praca egzegetyczna dotycząca tej książki została już wykonana (Bucholc 2012), ograniczę się jedynie do szczegółów potrzebnych do mojej argumentacji.

Skromne empirycznie opracowanie problemów trzech dzielnic typowego angielskiego regionu miejskiego mogło odnieść sukces teoretyczny w postaci doprecyzowania i unowocześnienia koncepcji władzy, stygmatyzacji i wykluczenia, ponieważ Norbert Elias kilkukrotnie miał okazję napisać do niej wstęp. 
Najpierw nadzorował jej część empiryczną jako promotor pracy dyplomowej, później pisał wstępy - najpierw mniej obszerny do wydania angielskiego, następnie do holenderskiego (ten zawiera najciekawsze innowacje teoretyczne) oraz już bardziej literacki wstęp do wydania niemieckiego. Jakkolwiek to zabrzmi, to właśnie fakt, że Elias zajmował się tą książką kilkanaście lat i wracał do jej tekstu kilkakrotnie, dopisując i przeredagowując go, zadecydował o sukcesie. Taki sam los spotkał $O$ procesie cywilizacji, $z$ dokładnie takim samym efektem. Obecnie takie praktyki są spotykane incydentalnie, a trajektoria karier uczonych rzadko kumuluje się wokół kilku stopniowo udoskonalanych, podlegających reedycji dzieł.

Elias tymczasem żył dostatecznie długo, aby móc dopisać krytyczne wstępy do kilku swoich najważniejszych prac i w tym zadaniu ich późne odkrycie było bardzo pomocne. Sądzę, że to właśnie stanowi o jego sukcesie. Uporczywe przemyślanie tych samych stron tekstu, wyników badań, wersów źródeł pozwoliło Eliasowi dołączyć i tak już mocno nasycone energią emocjonalną teksty do nowych łańcuchów wymiany intelektualnej, co zaowocowało nowymi pomysłami, kolejnymi przesunięciami akcentów, pogłębieniem i podkreśleniem najważniejszych wniosków. To z kolei stworzyło kapitał kulturowy odpowiedni do dalszej wymiany EE, a nawet umożliwiło jego instytucjonalne generowanie - wraz z powstaniem Norbert Elias Foundation i ustanowieniem „socjologii figuracyjnej" jako oficjalnego nurtu badawczego. Doprowadziło to do przekształcenia części EE w KK, a więc w prestiż przynależenia do ważnej sieci badawczej.

Analiza przyczyn legendy niemieckiego socjologa żydowskiego pochodzenia $z$ Wrocławia powinna być daleka od monokauzalności. Chciałbym mimo to podkreślić znaczenie względnie wysokiego KK Eliasa. Idąca za tym możliwość odczytania różnorodnych systemów symbolicznych, jak umiejętność czytania po łacinie, bardzo dobra znajomość literatury klasycznej, ale i popkulturowej (Elias uwielbiał czytać kryminały), nie daje recepty na sukces w świecie twórców literatury filozoficznej i socjologicznej, jednak ułatwia otwartość intelektualisty na nowe obszary empiryczne i umożliwia dostrzeżenie nowych konfiguracji teoretycznych. W badanym przypadku istotnym warunkiem był również moment przejścia, czas zamętu i przełomu, czyli wspomniane lata dwudzieste XX wieku w Niemczech i Europie, kiedy to żadna ze szkół myśli filozoficznej nie oferowała jednoznacznych rozwiązań problemów badawczych odziedziczonych po poprzednich pokoleniach. Emigracja, pomijając jej aspekt sentymentalny, powinna być traktowana $\mathrm{w}$ tym przypadku raczej jako stała sprzyjająca przestrzennemu rozwijaniu sieci interakcyjnych w nie mniejszym stopniu niż wytrwała lektura, która pogłębiała tę sieć w wymiarze wertykalnym.

Empiryczny przypadek kariery uczonego, który chciałem tutaj podjąć na nowo, pozwala sformułować kilka tez do dalszej weryfikacji. Przede wszystkim widać wyraźnie, że kreatywność w nauce nie jest uzależniona od wieku. Zdolność do zwrócenia uwagi na efekty swojej pracy intelektualnej nie zależy od tradycyjnie rozumianej drogi od tekstów „młodzieńczych” poprzez wiek „,doj- 
rzały” do okresu „późnego”, tekstów, którym przypisywane są różne szanse ujawnienia się kreatywności. Zdolność do kumulowania i przekształcania EE w znane dzieła naukowe zależy zarówno od warunków makro danej sieci, jej zdolności instytucjonalnych i możliwości reakcji na zmiany polityczne, jak i od poziomu mikro, na którym pojedyncze decyzje teoretyczne i empiryczne sumują się w postaci dorobku, dając wyraz danej sytuacji — stanu łańcuchów interakcyjnych. Ponadto widać wyraźnie, że w świecie uczonych nie można być znanym z powodów niezależnych od twórcy, na przykład dzięki niespodziewanemu odkryciu nieznanych wcześniej tekstów. Odnosząc to do danego przypadku - O procesie cywilizacji Eliasa w takiej formie, $\mathrm{w}$ jakiej autor przygotował je do druku, tuż przed drugą wojną światową było dziełem wystarczająco inspirującym i rzetelnie wykonanym, aby przynieść prędzej czy później oczekiwany efekt.

\section{BIBLIOGRAFIA}

Bucholc Marta, 2012, Osiadli i outsiderzy. Norbert Elias o inności i wykluczeniu społecznym, w: Maciej Gdula, Aleksandra Grzymała-Kazłowska, Renata Włoch (red.), Nowe rzeczywistości społeczne, nowe teorie socjologiczne. Dyskusje i interpretacje, Scholar, Warszawa.

Bucholc Marta, 2013, Samotność dtugodystansowca. Na obrzeżach socjologii Norberta Eliasa, Wydawnictwo Naukowe PWN, Warszawa.

Colfax David, 1966, Review: The Established and the Outsiders: A Sociological Enquiry into Community Problems by N. Elias and J. Scotson, „American Sociological Review”, t. 31, nr 5.

Collins Randall, 1998, The Sociology of Philosophies: A Global Theory of Intellectual Change, The Belknap Press of Harvard University Press, Cambridge.

Collins Randall, 2011 [2004], Łańcuchy rytuatów interakcyjnych, tłum. Katarzyna Suwada, Nomos, Kraków.

Dominiak Łukasz Marcin, 2012, Polifonia powolnych przemian [artykuł recenzyjny: Norbert Elias, O procesie cywilizacji. Analizy socjo- i psychogenetyczne], „Klio”, nr 20, s. 260-268.

Elias Norbert, 2013a, Notes on a Lifetime, w: Norbert Elias, Interviews and Autobiographical Reflections, tłum. Edmund Jephcott, University College Dublin Press, Dublin.

Elias Norbert, 2013b, A 'Jewish Portrait'. Interview with Herlinde Koelbl, w: Norbert Elias, Interviews and Autobiographical Reflections, tłum. Edmund Jephcott, University College Dublin Press, Dublin.

Elias Norbert, Scotson John, 1994, The Established and the Outsiders: A Sociological Enquiry into Community Problems, Sage, London.

Goodwin John, Hughes Jason, 2011, Ilya Neustadt, Norbert Elias, and the Leicester Department: Personal Correspondence and the History of Sociology in Britain, „The British Journal of Sociology”, t. 62, s. $677-695$.

Hackeschmidt Jörg, 1997, 'The Cultural Forces of the Group' - Norbert Elias as Pioneering Thinker of the Zionist Youth Movement. Two Previously Unknown Letters from 1920 and 1921, „Berliner Journal fur Soziologie", nr 3.

Hoffsommer Harold, 1966, Review: The Established and the Outsiders by Norbert Elias and John Scotson, „Social Forces”, t. 45, nr 2.

Jitschin Adrian, 2013, Family Background of Norbert Elias, „Figurations”, nr 39.

Rojek Chris, 2004, An Anatomy of the Leicester School of Sociology: An Interview with Eric Dunning, „The Journal of Classical Sociology", t. 4, s. 337-359. 
Schnädelbach Herbert, 1992 (1984), Filozofia w Niemczech 1831-1933, tłum. Krystyna Krzemieniowa, Wydawnictwo Naukowe PWN, Warszawa.

Seglow Peter, 2013, Norbert Elias — Some Personal Recollections, „Figurations”, nr 40.

\section{ON A SOCIOLOGY OF ACADEMIC CREATIVITY \\ ON THE MARGINS OF NORBERT ELIAS'S BIOGRAPHY}

\section{Summary}

This text contains initial reflections on the subject of the academic biography of Norbert Elias from the perspective of the theory of ritual interactions. The author outlines the spatial-temporal conditions that produced the emotional energy in Elias's works and to a large degree determined his great popularity in the second half of the $20^{\text {th }}$ century and now.

\section{Key words/słowa kluczowe}

Norbert Elias; history of sociology in the 20th century / historia socjologii w XX wieku; sociology of scientific creativity / socjologia twórczości naukowej 